\title{
Oil Pollution hazards from reception facilities On Sidi Krier Coast-Alexandria
}

\author{
Prepared by: \\ E.E.Siam \& M.M.Rfaat \\ Marine environmental protection program \\ Arab Academy for science and Technology and Maritime Transport
}

\begin{abstract}
:
Increased world demand on energy is accompanied by an increase on oil production and transport. The transport of a huge amount of oil from production field to consumption countries caused series problems to the marine environment. The actual study is focused on the oil pollution in the Egyptian northern coast waters. Water samples were taken and analyzed and the average dispersed oil concentration in ppm is determined. The oil industry and specially the reception facilities on board and on land are responsible for this pollution. The study details the reasons of the accumulated oil pollution and gives recommendations to reduce the marine environmental damage.
\end{abstract}

\section{Introduction}

Oil is the main source of world energy. The huge amount of oil world production reached $69,685,000$ barrels per day in 1996[1]. The number reflects from one side the economic needs for that type of fuel and the size of the problem of the sea water pollution by oil.

In the United States, the U.S. coast guard reported pollution spills from 1973 to 1997[2]. The greater volume of spills was 22 million gallons in 1975 and the smaller was IO million gallons in 1997.

An international oil spill statistics (1997)[3] showed that nearly 49 million gallons oil spilled world wide into the marine and inland environments from all sources as the result of 136 incidents during 1997.

The National Academy of Science in United States reported in 1980 that 1.5 million tons entered to the sea as a result of all shipping operations. 700,000 tons of this quantity is due to tanker operations, 400,000 tons are due to tanker accidents, 300,000 tons from bilges, 30,000 tons from docking, 20,000 tons from terminal operation and 50,000 tons from others.

The U.S. Coast Guard reported in 1997[4] that 174 different oil types are introduced into different water bodies. Also, the report showed that through 1992 only, the large majority of spills are believed to result from human error. The problem of oil spills and sea water pollution has two sides; On-Land and On-Board.

The On-Land problem was translated by governmental and nongo vernmental organizations into oil spill contingency plans [5]. Examples of these plans are the British Colombia Oil Spill Contingency plan. The original plan was prepared in 1991 after the Netscape barge spill in 1989 off of Greys Harbour and Exxon Valdez spill in 1990 in Price William. Alaska The plan was amended in 1992 and in 1997. The On-Board problem was realized by the International Maritime Organizations. Which concluded that, if it is to reduce pollution from spill, it 
must be at the source namely the ship and specially the oil tanker and for the objective of reducing human error. The International Convention for the Prevention of Pollution from ships 1973 and the 1978 protocol required an emergency plan to reduce oil pollution from ships in accidental case. Regulation 26 of MARPOL[6] give an objective of this plan is to provide guidance to master and offices aboard for their duties when oil pollution incident occurs or likely to occurs.

The regulation 26 requires that every oil tanker of 150 tons and any ship other than an oil tanker of 400 tons shall carry an oil pollution emergency plan.

\section{Reception operation in oil transport}

Reception operation has two meanings in oil industry. On-Board tankers reception facilities include all equipment and operations involved in oil loading and discharging. On-Shore reception facilities involve all equipment used in receiving and storage of all liquids and waste from ships.

The number of oil spills registered annually has been increasing. Most of the oil spills consist of oil contaminated bilge water and oily sludge (and not of oil contaminated ballast water or tank washing water from oil tankers) and such waste may be discharged from any ship, irrespective of type and size.

\section{There are several reasons for this} negative trend, e.g.:

- Increased world traffic with sub-standard ships.

- Lacks of operations for ships to deliver waste to port reception facilities.

- The lack of capacity to receive ship-generated waste is obvious in ports.
- Insufficient surveillance at sea, which makes the risk of discovery very small.

- Bureaucracy and high demands on evidence in order to tie a ship to a specific discharge.

According to international regula -tions discharges of oily and chemical wastes and garbage are not allowed in open waters. Such wastes should be stored onboard and delivered to port reception facilities. This is how it should be, but unfortunately this is too often not the case.

The main objective of the world strategy is to stop discharges from all types of ships-from large tankers to fishing vessels and pleasure crafts. The

strategy comprises three parts:

- Mandatory rules for ships to deliver their wastes in port, together with effective surveil lance and control systems, and international agreements on how to punish those who violate the rules.

- A fare and harmonized system between the countries on how ports should be allowed to recover their costs for receiving and treating ship-generated waste in environmentally acceptable ways.

- Investments to build new, or improve existing, reception facilities in nearly all ports.

It is important to resume the important guidelines for the prevention of pollution of the sea by oil from 


\section{Oil Pollution hazards from reception facilities}

machinery spaces of ships of less than 400 gross tonnages as:

Such ships should be fitted with approved oily-water separating or oilfiltering equipment and sufficient tank capacity for oily residues, which enable the ship to comply with paragraph (3) (b) of regulation $\mathrm{IO}$ of annex I of MARPOL 73/78.

Such ships should be equipped with holding $\operatorname{tank}(\mathrm{s})$ to retain generated oily bilge water and other generated oily residues on board for subsequent discharge to reception facilities, which enable the ship to comply with paragraph (4)(b) of regulation 10 of annex I of MARPOL 73/78.

Tanks required by paragraph I and 2 above should be equipped with pumping facilities and standard discharge connection to enable pipes/hoses of reception facilities to be connected.(ship should preferably be equipped, \& with-the quick Release connection of the European standard EN 1305, but may alternatively be equipped with a standard discharge connection referred to in regulation 19 of Annex I of MARPO-L--73/-7-8).The $\operatorname{tank}(\mathrm{s})$ should have adequate capacity taking into account the type and condition of the ship, trading pattern, time at sea, etc.

For ships of less than 24 meters long the administration may allow other arrangements than stated in paragraph 1-3 above.

\section{Pollution Evaluation of Oil Industry on the Egyptian Northern Coast}

The Egyptian Northern coast extends from Alexandria to the Egyptian-Libyan boarders. This coast was characterized by the soft white sands and the clear seawater. In the last two decades, this coast was privileged for Egyptian summer tourism where a lot of touristic villages were established.
In the last years, the seawater in most populated areas changed its color from clear topaz to green-brown with a lot of tar balls spreaded on seawater surface and along the shoreline. The reason was obvious: the young petroleum industry along this coast with large number of oil tankers changing from the Sumid terminal.

To evaluate the environmental damage caused to the sea and consequently to the shore, seawater samples were taken during the return leg from Europe of the Arab Academy Training Ship AIDA IV. The return leg approaches the territorial waters from the west and passing parallel to the Egyptian Northern coast to reach the Alexandria port.

Alexandria port is one of the heavy traffic ports of the Mediterranean Sea. Geographically, the port lies between latitude $310.13 \mathrm{~N}-31^{\prime} .20 \mathrm{~N}$ and longitude 290.78E 29'.86E. The port received over 4058 vessels called at Alexandria of different categories and the throughput reached 847 million tons during the year 1997. The port contains 71 berths handling different types of cargo (Seatrade [7]).Cargo ships come in the first place of the ships calling the port About $70 \%$ of the Egyptian foreign trade are served at this port. Inside the port there are large numbers of service boats, tugboats, floating cranes, supply vessels, military ships, submarines and dry docks. The total length of the berths is $40.000 \mathrm{~m}$. and the surface area is 7500000 square meters. Inside all these areas of operation, the different cargo handling systems are distributed along the berths. The port dimensions are 7$\mathrm{km}$ length and $2 \mathrm{~km}$ maximum width. The depth of the water is between 5.5 to 18 in (MRCC [81). The port contains two main basins, the inner of which covers about 200 acres and extends from Ras El-Tin lighthouse top El- 
Kabary area, and the outer basin covers about 450 acres and extends from the end of the inner basin to the end of the breakwater. The port contains Alexandria shipyard in the outer basin with two building berths of capacity up to $20000 \mathrm{wt}$ for cargo ships and 38000 wt for bulk carriers, four slipways and two dry-docks-85000 wt and 10000-wt capacity. There is also Egyptian Shipbuilding and Repair Company in the inner harbor with a slipway and floating dock-6000 ton capacity (Seatrade [7]).

All petroleum activities are concentrated on the western side of Alexandria port from the entrance to Sidi Kreir, $27 \mathrm{~km}$ west of Alexandria. The centers of petroleum activities are the petroleum harbor, El-Mex industrial zone, El-Agamy region, and Sidi Kreir and Al-Alamein region.

Samples of seawater (42 samples) were taken along the return leg and analyzed to prove the existence of oil pollution by finding the oil fingerprints; figures $(1,2)$. The quantity in ppm of the dispersed oil was determined experimentally. It was found that the oil concentration varies from $6 \mathrm{ppm}$ to nearly $65 \mathrm{ppm}$ at the port of Alexandria with an average value parallel to the northern coast of $23 \mathrm{ppm}$. The average estimated spilled oil in a wide region of the northern coast was $2.3-\mathrm{kg}$ oil per ton of seawater.

A review to the petroleum activities along this coast points that the major contributor in this pollution is the SUMED terminal, which is the major activity and having the largest reception facilities in this area. This line is belonged to the Arab Petroleum Pipelines Co. SUMED is an Egyptian Company created for the purpose of pipelines construction to transfer crude oil from AIN-SUKHNA at Suez Gulf to SIDI-KREIR at the Mediterranean sea.
The charging oil terminal of this line is located at Sidi-Kreir at $27 \mathrm{~km}$ from the port of Alexandria. The terminal station has offshore facilities of six-single mooring load vessels from 150000 DWT and 350000 DWT through floating hoses.

It is documented that the mooring points are supplied by deballasting facilities working as receiving facilities of the dirty ballast at the rate from 3000 to $5000 \mathrm{M}^{3} / \mathrm{hr}$. The SUMED docum ents [9] states that: "the dirty ballast received from tankers is treated in the onshore treating plant at the rate of $8000 \mathrm{cu}$. meters per hour. The plant consists of four fixed roof tanks each 30.000 cu. meters nominal capacity, each equipped with four skimmers to skim.

Separated oil,(water with poor oil content is discharged to concrete basins containing packages of tilted plate interceptors to separate oil from water, then to a holding basin for final check of water cleanliness and finally (water is discharged to Sea with an average oil content of six parts per million and with a maximum of ten parts per million, a level far better than the International requirements. The treatment of the deballast water is a mechanical process and thus avoids the risks associated with thermal and chemical processes.

\section{Conclusions and recommen - dations:}

The measured average value of the hydrocarbon concentration in seawater was found to be $23 \mathrm{ppm}$ it must be noted that this average value was measured at a distance of nearly I Omiles from the shoreline. This means that the pollution may increase on approaching the coast.

This quantity of pollution could be explained by the increased activity of 


\section{Oil Pollution hazards from reception facilities}

oil industry along the northern coast. But this is not only the reason, this industry is partially responsible by some release of uncontrolled treated water.The major part of this pollution returns to the vessels navigating in this area. Some of these vessels releases important quantity of ballast water while others releases the bilge water.

The concentration of $6 \mathrm{ppm}$ for the released water at SUMED outlet is $1 / 3$ of the measured value.This largedifference may be due to one of two reasons or both of them.

The first reason of the actually increased concentration of the oil content in seawater along the northern coast may be due to the meteorological conditions in this area. The prevailing wind is NW and it is always perpendicular to the coastline. The wind generates waves, which may push surface water from the northwest to the port area passing along the shoreline.The other reason of the measured oil concentration may be due to release of uncontrolled discharged water from the treating plant.At any situation the mixing of the released discharge from the plant with the seawater must be subject to the prevailing wind, the surface currents and the underwater current. The result needs no explanation; oil pollution is accumulated under no mixing and no dilution.

The damage caused to the marine environment by oil pollution takes many years to be repaired. A small amount of oil enters the marine environment consumes huge amount of dissolved oxygen to decay. The best solution to protect is to stop releasing oil in seawater.

Stopping marine pollution at the northern coast requires adequate mechanism to ensure that no uncontrolled releases from the oil companies. Also requires the control of the Egyptian Coast Guard to prevent releases from the vessels navigating in this area.

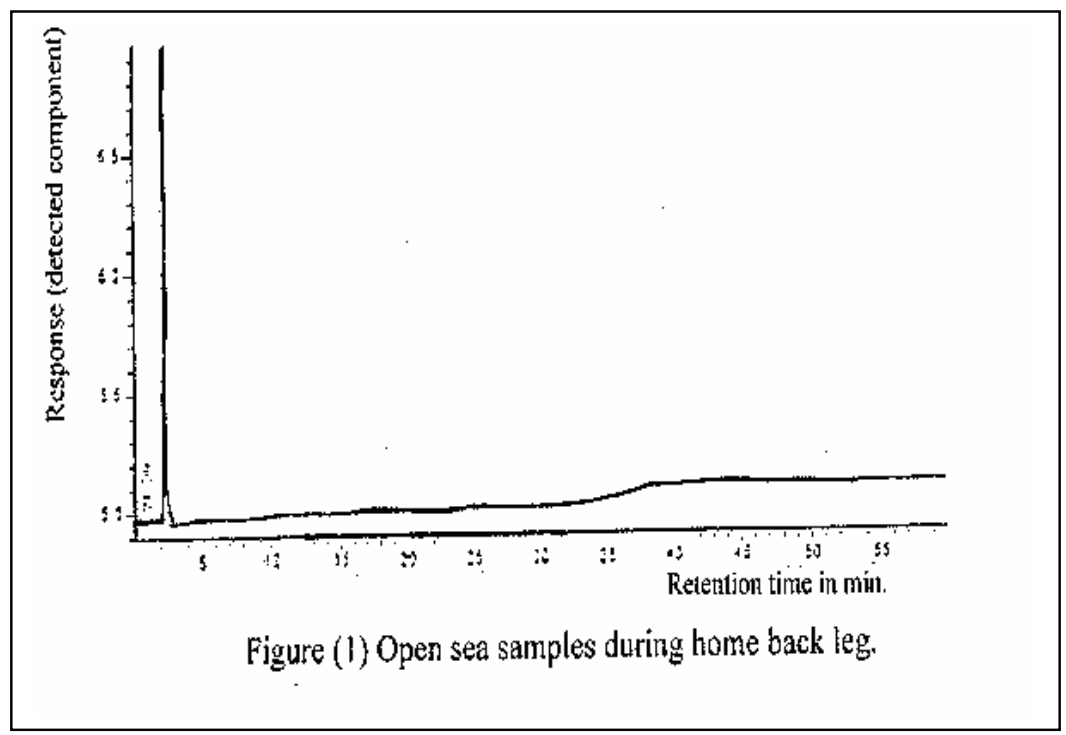




\section{E.E.Siam \& M.M.Rfaat}

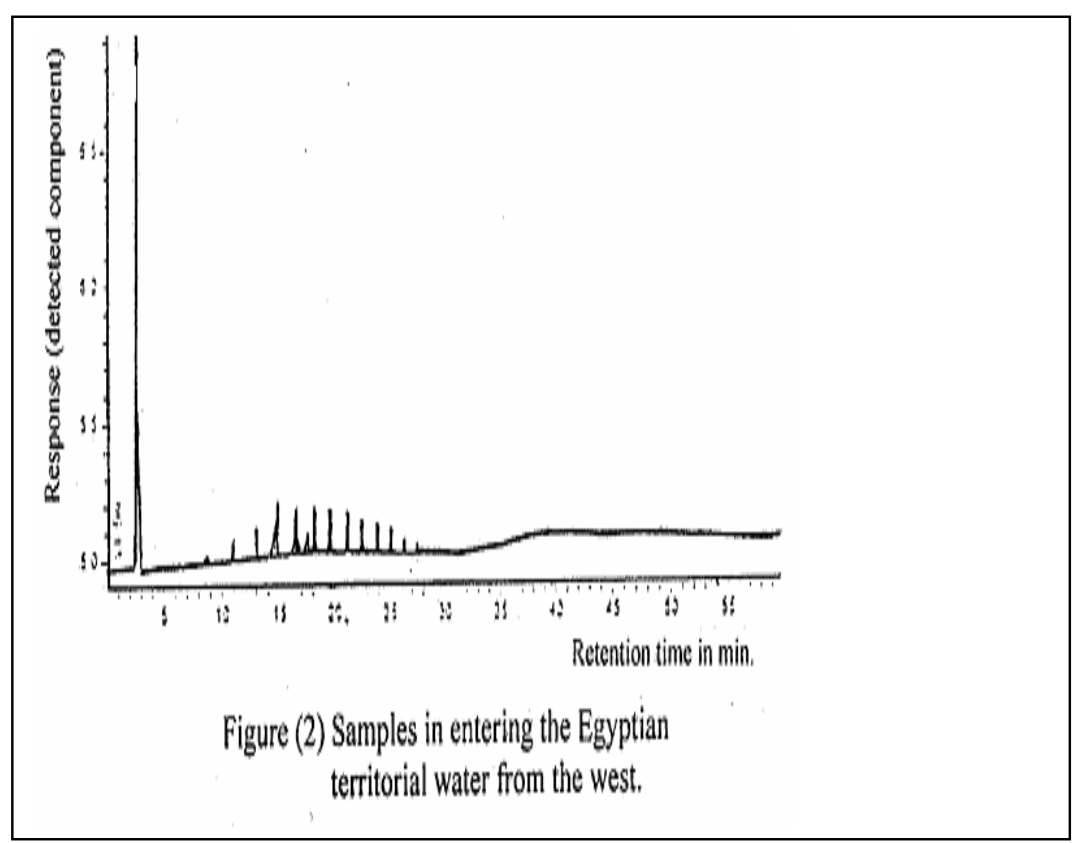

\section{References}

1. BP Statistical Review of World Energy, 1997.

2. Polluting incident Compendium-U.S. Coast Guard report, 1973-1997.

3. International Oil Spill Statistics, 1997-Reports for Spill Professional, 1997.

4. Annual Data and Graphics-U.S. Coast Guard report, 1969-1997.

5. B.C. Marine Oil Spill Contingency plan-B.C. Ministry of Environment, Lands \& Parks, 1997.
6. MARPOL, 73/78, International Maritime Organization, London1978.

7. Arab Shipping GuideEgypt. Seatrade Review, August 1998.pp. 36-37, 1998

8. Activities of the Egyptian Harbon and Suez Canal during 1992. The statistical annual report, Vol. 10. Part 2. MRCC (Maritime Research and Consultation Center). Arab Academy for Science and Technology and Maritime Transport, 1993

9. SUMED annual report Alexandria, Egypt, p. 2 1. 


\section{Oil Pollution hazards from reception facilities}

\section{مخاطر التلوث بالزيت من محطات استقبال مخلفات السفن فى منطقة سيدى كرير بالإسكندرية}

$$
\text { د/ محمد منير رفتت1 \& د إيمان إبراهيم صيام2 }
$$

رئيس قسم حماية البيئة البحرية بالأكاديمية العربية للعلوم والتكنولوجيا (1)

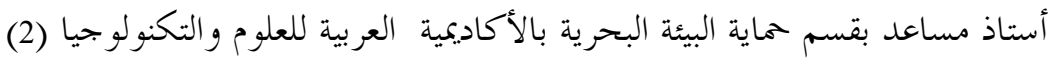

هدف هذه الدارسة المى إيجاد الأسباب الرئيسة لظهور التلوث بالزيت في المياه الساحلية المصرية وخاصة فن

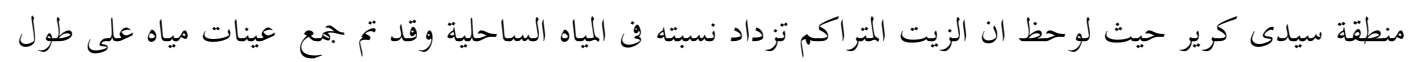

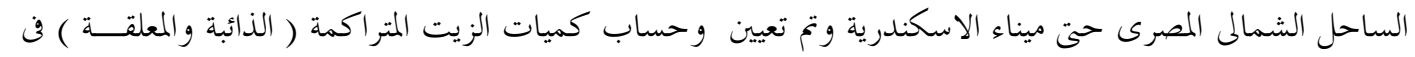

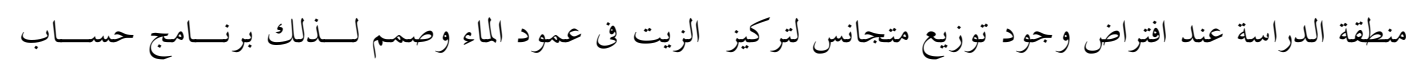

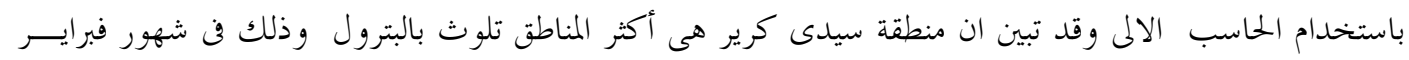

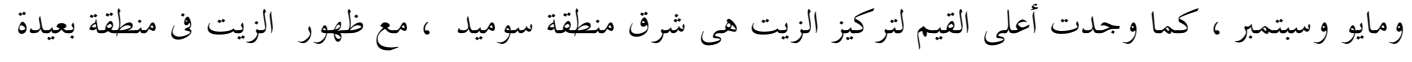

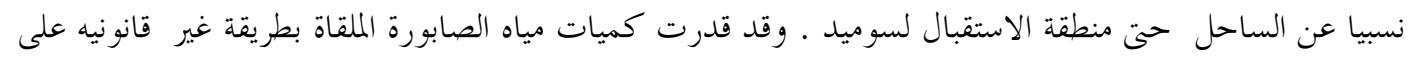

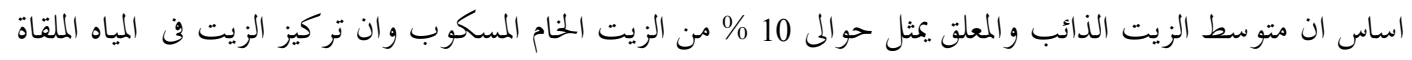

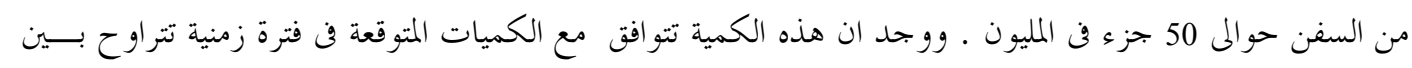

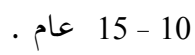

وتوصى هذه الدارسة باستخدام وحدات صغيرة لاستقبال مياه الصابورة ومعالجاقا ف فئل الخطات المختلفة

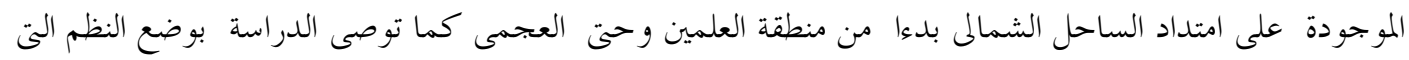

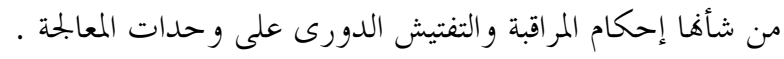

